\title{
Poverty and Inequality among Social Groups in Rural India
}

\author{
Woojin Kang**
}

\begin{abstract}
This study examines economic disparity among social groups in rural India. While the pace of poverty reduction for disadvantaged groups, who benfited from both economic growth and redistribution, surpassed that of other caste households during the period from 1999-2006, they remain the most poor among the rural poor. This study's decomposition analysis confirms that they are not only less wealthy than other castes but also have lower returns on their assets due to discrimination or lower productivity. In addition, the contribution of the latter has become larger over time, implying that programs established by the government and development agencies to reduce economic disparity between two groups may be less effective. For example, an antipoverty program is vital, and the government also needs to strengthen the effectiveness of the current affirmative action programs. There are also lessons from South Korea's past experience to be shared for the improvement of productivity.
\end{abstract}

Keywords: poverty, inequality, decomposition, affirmative action

\section{INTRODUCTION}

The Indian economy has rapidly grown, with an average growth rate of $7 \%$ from 1993 to 2010, and this high growth rate has contributed to improving the lot of millions of poor people (Anand et al. 2014). ${ }^{1}$ However, one in three Indian households is still deemed to be poor, and the gap between rich and poor has widened, hampering the poverty-reducing effect of growth. In addition, economic disparity can be found

\footnotetext{
* Woojin Kang is an associate fellow in the Department of Public Finance and Social Policy at the Korean Development Institute (KDI), Sejong-si, South Korea. E-mail: woojin.kang@ kdi.re.kr. I am grateful to three anonymous referees. I also thank Y. Choi for valuable research assistance. The views expressed, however, are personal and not necessarily of the institution with which the author is affiliated.

1. The average annual rate of poverty reduction in rural India, for example, surpassed that of poverty reduction in urban India (Anand et al., 2014).
}

Manuscript received June 15; out for review July 1, 2015; review completed August 1, 2015; accepted August 6, 2015.

The Korean Journal of Policy Studies, Vol. 30, No. 2 (2015), pp. 119-145.

(C) 2015 by the GSPA, Seoul National University 
between those categorized as belonging to "other castes" (OC), on the one hand, and other disadvantaged groups (non-OC), which include the "scheduled castes" (SC), "scheduled tribes" (ST), and "other backward castes" (OBC), on the other. ${ }^{2}$

The traditional structure of Hindu social order consists of four hierarchical varnas (classes), Brahmin, Kshatriya, Vaishya, and Shudras, for whom various socioeconomic, political, educational, and religious functions are prescribed (Kumar 2014). The SCs, or the Ashprishyas (untouchables), identified on the basis of exclusion from the varna system, make up the most underprivileged class of the Indian society, but although they have historically suffered from social stigma due to their "untouchability" and thus have been socially excluded, they have always been a part of mainstream society. The STs are distinguished by their tribal culture and physical isolation (many of them are residents of specially protected "scheduled areas"). OBC denotes newly distinguished group who are accorded political reservations after SC and ST. The OBC are largely a heterogeneous collection of Hindu low castes, some non-Hindu communities, and some tribes that were not previously included in the SCs/STs. Because the STs were never considered part of the Hindu social hierarchy and therefore, unlike the SCs, have been geographically excluded, the Indian government has developed largescale affirmative action programs to address their socioeconomic backwardness, establishing reserved quotas for members of minority groups in higher education, public sector employment, and the government. While the deep-rooted social and economic disadvantages of these groups persist, it might be a positive signal that the pace of poverty reduction in the non-OC groups surpassed that of the OC groups in the period from 1999 to 2006.

Owing the recent structural transformation resulting from comprehensive reforms that have been instituted since 1991 and the changing patterns of poverty reduction, the existing social group literature with respect to the welfare gap between the OC and the non-OC groups might be less informative for public policy because this research was mostly based on data collected in 1980 and 1990s. The objectives of the present study are therefore to explore the attributes that account for the welfare gap between the $\mathrm{OC}$ and the non-OC groups and to trace how they have changed over time. Furthermore, I attempt to decompose poverty reduction into two components, economic growth and inequality, and to look into how they vary among social groups.

2. Prior to the Mandal Commission's report in 1990, household surveys seeking information about social group identity used three categories: SC, ST, and OC (i.e., non-SC/ST, or higher castes), but there were groups that fit none of these categories. In 1991, the National Sample Survey (NSS), the oldest and continuing household survey, added OBC as a category (Bhaumik \& Chakrabarty 2008). 


\section{LITERATURE REVIEW}

Among various types of inequality, the most challenging one is perhaps castebased inequality because social exclusion and discrimination restrict not only the social and economic mobility of the current generation but also of successive generations owing to strong marital endogamy (Clark \& Landes, 2013) Non-OC households have been denied educational and income-generating opportunities, and these deprivations and impoverishments have in turn led to economic immobility, further lowering their productivity. Even if they receive sufficient education, this educational progress has not translated into occupational improvement in the labor market, as Takahiro Ito (2009) and Jhilam Ray and Rajarshi Majumder (2013) observe.

Viktoria Hnatkovska, Amartya Lahiri, and Sourabh Paul (2013) argue, however, that India's recent structural changes and public affirmative interventions in higher education and public sector employment have broken down caste-based historical barriers to social and economic mobility. They observe that middle-income households have seen the sharpest change in intergenerational income mobility. ${ }^{3}$ Ashwini Deshpande (2000) decomposes total inequality in Kerala, India, into within-group inequality and between-group inequality and shows that total inequality mainly derives from the former, a result that is in line with the findings from the empirical literature on inequality decompositions for race, gender, spatial units, and so forth in an international context that the inequality between groups has not exceeded $15 \%$ in many cases (Kanbur, 2003). However, despite the smaller contribution of betweengroup inequality to overall inequality, it contributes to the deepening of the social cleavage, which in turn threatens the stability of the society.

Poverty is persistent in the non-OC groups because of their economic and social backwardness. They tend to be located in remote areas where access to resources is limited. Another structural constraint is social stratification; non-OC groups suffer various kinds of discriminations. Kaivan Munshi and Mark Rosenzweig (2006), for instance, find that the caste system hinders economic mobility of individuals despite the movement into nontraditional occupations that economic liberalization during the1990s made possible. Similarly, Ito (2009) suggests a significant caste-based "job" discrimination due to higher entry costs against, although he finds no evidence of wage discrimination in regular employment. Others examine the difference in welfare outcomes such as consumption expenditure and find that a substantial degree of inequality can be attributed to varying returns on household assets (Bhaumik \&

3. This change might be comparable to the recent shaper pace of poverty reduction in the non-OC groups that the present study observes. 
Chakrabarty, 2006; Kijima, 2006; Gang et al., 2008). Thus, economic studies related to Indian caste system tend to fall into two strands: studies of caste-based discrimination that examine the wage differential, for example, and studies of economic disparity in welfare outcomes such as consumption expenditure (Borooah 2005).

Affirmative action literature reports the positive impact of public interventions primarily designed to help caste-based groups (e.g., political reservation or quotas in government jobs for disadvantage groups). In 1996, India granted local rural governments the power to adopt a democratic decentralized system that would enable them to become more accountable to their local residents (Heller, Harilal, \& Chaudhuri, 2007). Under such a decentralized governance system, the goal of affirmative action programs was to make it more likely that redistributive policies that favored disadvantaged groups were effected. ${ }^{4}$ Rohini Pande (2003) observes that the rise in minority representation leads to increased spending on ST welfare programs and more state government jobs being set aside for minorities. Furthermore, ST reservations have enhanced the welfare of ST households. Timothy Besley, Pande, and Vijayrendra Rao (2005) find that SC/ST groups are significantly more likely to attend Gram Sabha meetings than other groups, and tend to make decisions leading to a higher incidence of policies targeted towards these groups. Although assessing the effect of affirmative action programs is not the objective of the present study, my decomposition analysis of change in poverty level into growth and redistribution might partly reflect their effect during the period from 1999 to 2006, as the analysis draws on a couple of findings from empirical studies that directly assessed the impact of affirmative action programs.

With this in mind, my goal is first to examine attributes that account for economic disparity, drawing on more recent rural representative household surveys collected in 1999 and 2006. In particular, I focus on how the relative contributions of household endowment and their returns on the economic gap between social groups have changed over time. Although a couple of studies have analyzed the economic disparity between OC and the non-OC groups (e.g. Kijima 2006), their findings and the impli-

4. The idea that decentralization aids in redistribution of wealth is based on the assumption that under a decentralized system, decisions about how to allocate resources better reflect local preferences and encourage the participation of local citizens, thereby resulting in greater efficiency of resource allocation (Tiebout, 1956; Oates, 1972; Putnam, 1993; Klugman, 1994). However, according to recent studies that examine the effect of decentralization in developing countries (e.g., Blair, 2000; Crook and Sverrisson, 2002), while participation is generally observed to have improved across all countries, the extent of poverty alleviation is country specific and dependent on the level of development. India shows high performance in both areas. There have also been polarized debates around affirmative action programs in India. For example, see Deshpande 2013. 
cations of their research may be less relevant to the recent India, where patterns in poverty reduction among social groups have been changing. In addition, rapid structural transformation toward high-productivity dynamic sectors has made the productivity gap between social groups disproportionately bigger than the wealth gap, and the growing private sector has likely hampered the impact of affirmative action programs that have improved the living stands of non-OC groups to some extent. Because I drawing on the relatively new dataset covering the postreform periods, my analysis on poverty and inequality between social groups could reflect the consequences of India's recent transformation.

Second, while the earlier studies mostly examine inequality in consumption expenditure, I analyze differences in the two types of household living standards indicators; that is, I consider not just disparity in household per capita consumption expenditure but also difference in the incidence of poverty. Therefore, my analysis provide mores concrete evidence pertaining to the welfare gap between OC and non-OC groups. Furthermore, I examine in detail the effect of household assets on household poverty as well as on per capita consumption. For this, I use three kinds of proxy variables: the size of land holding, number of household livestock per capita, and number of household productive assets per capita. Although these three kinds of assets play an important role in the living standards in rural Indian households, the last two variables are often omitted in previous studies.

The third contribution of the present study is that it provides an assessment of the impact of growth and inequality on poverty reduction between 1999 and 2006 by decomposing the magnitude of change in the incidence of poverty into the effects of growth and redistribution. Hence, one can see how households in different social groups have differently benefited from economic growth.

The following section introduces data used in this study. The fourth section discusses econometric methods for determining household consumption expenditure and poverty as well as decomposition analysis. The fifth section offers econometric results, and the final section provides a summary and policy implications.

\section{DATA}

The present paper draws upon the Rural Economic and Demographic Survey (REDS) of the India's National Council of Applied Economic Research designed as a nationally representative multi-purpose rural household and village surveys. Data for REDS was first collected in 1971, and subsequent surveys were conducted in 1982, 1999, and 2006. The survey is divided into three parts and collects detailed household 
and village information across various states in rural India.

The first part provides information on a number of important household characteristics such as household income and demographics. The second part collects information about individual and household characteristics, education, labor participation, disaggregated income by source, household food and nonfood consumption expenditure, agricultural activities, and land holdings and other assets. The third part provides information about the local economic and political structure, the infrastructure, and the provision of public goods such as schools, health service, financial institutions, and other social services.

The numbers of sample households in the 1999 and 2006 surveys are 7,474 and 8,659 respectively; of these, 5,883 rural households were interviewed in both rounds. The final sample size used in the present study are 4,743 and 4,503 panel households drawn from the 5,883 panel sample (some panels were excluded because observations of particular variables were missing). ${ }^{5}$ In order to quantify the contributions of characteristic and structural components to the welfare gap proxied by difference in consumption and poverty incidence and to explore changes in their roles between 1999 and 2006, I used the Blinder-Oaxaca type decomposition methods with cross-sectional data rather panel data.

Table 1 offers definitions and mean values of key variables from the 1999 and 2006 datasets. These variables used in the model specification of the regression analysis reflect the standard model of consumer behavior in developing countries. Variables such as the age of household head, dependency burden, and the size of land holdings and other household assets partly capture permanent income or conform to the lifecycle hypothesis, while variables such as whether a household head is a female or not, whether a household head has a spouse, and the share of female members within a household capture intrahousehold bargaining models. In particular, the female share is often treated as a proxy for bargaining power in the literature (Deaton 1992; Imai, Gaiha, \& Kang 2011; Kang \& Imai 2012; Butle, Tu, \& List 2015).

I also include the square terms of the age of the household head in order to show the nonlinear effects of the age of household head on household consumption. Generally, it is found to be hump-shaped in developed countries due to declining labor productivity

5. Relying on panel data often raises a concern of attrition bias. Although the panel sample in REDS is designed to be representative of rural areas, the present study checked that by comparing sample size and distribution across demographical household characteristics from both the 1999 and 2006 cross-sectional data and panel households. The assessment confirmed no evidence of nonrandom attrition, and the results of the assessment are available upon request. 
Table 1. Summary Statistics of Key Variables by Social Groups

\begin{tabular}{|c|c|c|c|c|c|c|c|c|c|c|c|c|}
\hline \multirow{3}{*}{ Variable } & \multicolumn{6}{|c|}{ REDS 1999} & \multicolumn{6}{|c|}{ REDS 2006} \\
\hline & All & OC & $\begin{array}{l}\text { Non } \\
\text { OC }\end{array}$ & SC & ST & OBC & All & OC & $\begin{array}{l}\text { Non } \\
\text { OC }\end{array}$ & SC & ST & OBC \\
\hline & Mean & Mean & Mean & Mean & Mean & Mean & Mean & Mean & Mean & Mean & Mean & Mean \\
\hline $\begin{array}{l}\text { In (cons) } \\
\text { (log of monthly } \\
\text { household } \\
\text { consumption } \\
\text { expenditure in } \\
\text { rupees) }\end{array}$ & 5825 & 6915 & 5342 & 5204 & 4344 & 5549 & 6597 & 8095 & 5929 & 5565 & 4699 & 6244 \\
\hline $\begin{array}{l}\text { poverty } \\
\text { ( } 1 \text { if a household is } \\
\text { in poverty) }\end{array}$ & 0.303 & 0.191 & 0.352 & 0.39 & 0.530 & 0.31 & 0.229 & 0.15 & 0.26 & 0.31 & 0.41 & 0.226 \\
\hline $\begin{array}{l}\text { fhead } \\
\text { ( } 1 \text { if household } \\
\text { head is female) }\end{array}$ & 0.053 & 0.061 & 0.050 & 0.04 & 0.034 & 0.053 & 0.097 & 0.11 & 0.09 & 0.09 & 0.08 & 0.09 \\
\hline $\begin{array}{l}\text { age } \\
\text { (age of household } \\
\text { head) }\end{array}$ & 49.3 & 50.92 & 48.58 & 48.3 & 46.5 & 49.01 & 51.1 & 53.3 & 50.2 & 49.1 & 48.9 & 50.7 \\
\hline $\begin{array}{l}\text { married } \\
\text { ( } 1 \text { if household } \\
\text { head has a spouse) }\end{array}$ & 0.892 & 0.885 & 0.895 & 0.891 & 0.899 & 0.895 & 0.870 & 0.857 & 0.876 & 0.879 & 0.896 & 0.872 \\
\hline $\begin{array}{l}\text { primary } \\
\text { ( } 1 \text { if household head } \\
\text { completed primary } \\
\text { school) }\end{array}$ & 0.22 & 0.20 & 0.23 & 0.23 & 0.21 & 0.22 & 0.24 & 0.22 & 0.24 & 0.20 & 0.20 & 0.27 \\
\hline $\begin{array}{l}\text { second } \\
\text { ( } 1 \text { if household head } \\
\text { completed secondary } \\
\text { school) }\end{array}$ & 0.29 & 0.39 & 0.25 & 0.23 & 0.174 & 0.27 & 0.233 & 0.29 & 0.21 & 0.21 & 0.12 & 0.22 \\
\hline $\begin{array}{l}\text { upper second } \\
\text { ( } 1 \text { if household head } \\
\text { completed upper } \\
\text { secondary school) }\end{array}$ & 0.04 & 0.05 & 0.038 & 0.03 & 0.021 & 0.044 & 0.086 & 0.12 & 0.08 & 0.07 & 0.04 & 0.07 \\
\hline $\begin{array}{l}\text { higher } \\
\text { ( } 1 \text { if household head } \\
\text { completed university } \\
\text { or master) }\end{array}$ & 0.038 & 0.056 & 0.030 & 0.02 & 0.005 & 0.037 & 0.065 & 0.09 & 0.05 & 0.05 & 0.01 & 0.06 \\
\hline $\begin{array}{l}\text { female share } \\
\text { (share of female } \\
\text { members in } \\
\text { household) } \\
\end{array}$ & 0.473 & 0.472 & 0.473 & 0.48 & 0.478 & 0.470 & 0.494 & 0.49 & 0.49 & 0.49 & 0.49 & 0.49 \\
\hline $\begin{array}{l}\text { dependency } \\
\text { (dependency ratio } \\
\text { of household) }\end{array}$ & 0.369 & 0.366 & 0.371 & 0.397 & 0.385 & 0.360 & 0.364 & 0.355 & 0.369 & 0.378 & 0.368 & 0.366 \\
\hline $\begin{array}{l}\text { pclivestk } \\
\text { (per capita number } \\
\text { of livestock) }\end{array}$ & 2.001 & 1.849 & 2.069 & 1.38 & 2.562 & 2.202 & 2.367 & 2.32 & 2.39 & 1.75 & 3.65 & 2.38 \\
\hline $\begin{array}{l}\text { pcproasset } \\
\text { (per capita number } \\
\text { of productive assets) }\end{array}$ & 7.631 & 8.672 & 7.169 & 6.41 & 7.670 & 7.326 & 8.902 & 10.2 & 8.31 & 7.47 & 8.7 & 8.504 \\
\hline $\begin{array}{l}\text { land } \\
\text { (the size of } \\
\text { household's land } \\
\text { holdings in acres) }\end{array}$ & 3.935 & 5.263 & 3.346 & 1.91 & 2.602 & 3.921 & 1.635 & 1.86 & 1.53 & 0.89 & 1.27 & 1.778 \\
\hline observations & 5,672 & 1,741 & 3,931 & 837 & 436 & 2,658 & 5,625 & 1,734 & 3,891 & 824 & 433 & 2,634 \\
\hline
\end{tabular}

Source: Author's calculation based on REDS 1999 and 2006. 
beyond certain threshold of age cohort (e.g. Hur 2005; Kang 2015). However, it often appears to be U-shaped in developing countries, reflecting the fact that many developing countries are agrarian economies. In such economies, the older the household's head is, the more income the household tends to have and the greater household consumption; households with elderly members tend to own more assets. In a similar vein, I include the square terms of female share and the size of the land holdings. Because land is one of the most important household assets in developing countries (providing collateral for credit), the size and utilization of land holdings affects the level of household living standards to great extent (Binswanger \& Siller 1984; Eswaran \& Kotwal 1986; Lopez \& Valdes 1997). Given the substantial proportion of small-scale farmers in rural India and the diminishing marginal returns of land, it is important to investigate the nonlinear effect of land on household per capita consumption (Finan, Sadoulet, \& de Janvry 2005). ${ }^{6}$

As Table 1 shows, both the $\mathrm{OC}$ and the non-OC groups enjoyed economic growth in the sample period, although the former proportionately more benefited - the monthly household per capita consumption for the $\mathrm{OC}$ households increased by approximately 15\% between 1999 and 2006, while that of the non-OC households increased by $10 \%$. Rural India in this period witnessed a significant achievement in poverty reduction; the overall poverty ratio declined from $30 \%$ in 1999 to $22.9 \%$ in 2006 . The poverty ratio for non-OC groups decreased sharply, from $35 \%$ to $26.4 \% .^{7}$

At the disaggregated level, the incidence of poverty was higher among STs, followed by SCs and OBCs, in that order. Table 1 also shows that OC households were better off than those in the non-OC group in terms of human capital (for example, the level of educational attainment of the household head in OC households was higher) and productive assets (for example, more land). Poverty incidence is strongly correlated with level of human and physical capital and is also affected by regional variations. One empirical study from the 1990s of regional differences in poverty reduction in rural Indian states showed that there are two main routes to poverty reduction, growth and education, that had different results across the states (Datt \& Ravallion 1998).

In sum, although many of the poor in both the OC and the non-OC groups appear to have benefited from either economic growth or redistribution of resources, in 2006, approximately $23 \%$ of rural Indian households still lived below the poverty line, and

6. Frederico Finan, Eisabeth Sadoulet and Alain de Janvry (2005) show how the marginal welfare value of land varies with its size.

7. There are a couple of reports estimating the incidence of poverty in rural India (for estimates, see Biradar 2012) that slightly vary. My estimates are close to those of the planning commission of India. See Biradar 2012 for more details. 
poverty was highly concentrated in non-OC groups; nearly $80 \%$ of the poor households in 2006 were occupied by members of non-OC groups.

\section{METHODOLOGY}

\section{Determinants of Household Consumption}

In investigating the determinants of household consumption in developing countries such as India, it is important to take account of unobserved geographic effects on the level of living standards, as the location of a household might be an exogenous factor determining the household's welfare and correlate with the explanatory variables describing a household's characteristics. Omitting the regional controls could result in biased estimates (Van de Walle \& Gunewardena, 2001; Kijima 2006).

I estimate the $\log$ of per capita consumption expenditure $\left(\ln c_{i j k}\right)$ for $i^{\text {th }}$ household of social group $j$ in $k^{\text {th }}$ village, taking into account a vector of household characteristics $\left(X_{i j k}\right)$, village fixed effects $\left(\lambda_{k}\right)$ and a random error term $\left(\varepsilon_{i j k}\right)$

$$
\ln \left(c_{i j k}\right)=\alpha_{j}+X_{i j k} \beta_{j}+\lambda_{k}+\varepsilon_{i j k}
$$

where $\alpha_{j}$ is a constant error term.

Household characteristics $\left(X_{i j k}\right)$ include the age of the household head, gender of the head of household, his or her marital status, the share of female members, the dependency burden, level of educational attainment of the household head, and the size of land holdings and household assets proxied by the number of livestock and productive assets per capita. As religion is an important factor determining consumption behavior, I also include a dummy variable for whether the household head is Hindu or not.

\section{Determinants of Poverty}

For the determinants of poverty, I use a conditional fixed-effects logistic model in order to take account of village fixed effects.

$$
P\left(y_{i j k}=1 \mid \lambda_{i j}, \beta_{j}\right)=\frac{\exp \left(\lambda_{i j}+X_{i j k}\right)}{1+\exp \left(\lambda_{i j}+X_{i j k}\right)}
$$

where $y_{i j}$ is a binary choice variable, assigned a 1 if household per capita consumption 
expenditure is lower than the national poverty line (i.e., the minimum expenditure per capita to fulfill individual's basic food and nonfood needs) $\mathrm{f}$ and 0 otherwise. For household characteristics, the same set of explanatory variables in line with the determinants of consumption expenditure is used.

\section{Decomposition Analysis}

\section{Decomposition of Disparity}

I carry out a linear Blinder-Oaxaca decomposition (Blinder 1973; Oaxaca 1973) to calculate the mean difference in consumption expenditure per capita and a nonlinear decomposition to calculate the mean difference in the likelihood of poverty between the OC and the non-OC groups. Following Myeong-Su Yun (2004), the general form of decomposition at the mean level can be expressed as follows:

$$
\begin{aligned}
\bar{V}_{O C}-\bar{V}_{N O C}= & \sum_{i=1}^{k} W_{\triangle X}^{i}\left[\overline{\left(\overline{F\left(X_{O C} \beta_{O C}\right.}\right)}-\left(\overline{F\left(X_{N O C} \beta_{O C}\right.}\right)\right]+ \\
& \sum_{i=1}^{k} W_{\triangle \hat{\beta}}^{i}\left[\overline{\left(\overline{F\left(X_{N O C} \beta_{O C}\right.}\right)}-\left(\overline{F\left(X_{N O C} \beta_{N O C}\right.}\right)\right]
\end{aligned}
$$

where $V$ is a dependent variable indicating, in the present study, consumption expenditure per capita $(\ln c)$ or the probability of poverty $(P)$ and the subscript, $i, j$, and $k$ are suppressed for simplicity. Weights are given below.

$$
\begin{aligned}
& W_{\Delta X}^{i}=\frac{\left(\bar{X}_{O C}^{i}-\bar{X}_{N O C}^{i}\right) \beta_{O C}^{i}}{\left(\bar{X}_{O C}-\bar{X}_{N O C}\right) \beta_{O C}}, \\
& W_{\Delta \hat{\beta}}^{i}=\frac{\bar{X}_{N O C}^{i}\left(\beta_{O C}^{i}-\beta_{N O C}^{i}\right)}{\bar{X}_{N O C}\left(\beta_{O C}-\beta_{N O C}\right)}, \text { and } \sum_{i=1}^{i=N} W_{\Delta X}^{i}=\sum_{i=1}^{i=N} W_{\Delta \hat{\beta}}^{i}=1
\end{aligned}
$$

The first term in equation 5 indicates the contribution of different households' characteristics or assets to the mean difference of the dependent variable: this is the characteristic component $(\mathrm{C})$. The second term represents the contribution of different returns to those households' characteristics: this is the structural component (S). A detailed decomposition methodology using weights as an extension of the BlinderOaxaca decomposition is proposed by Yun (2004). The characteristic component of certain key variables could reflect differences in household wealth resulting from discrimination (e.g., limited access to labor markets among the lower castes). In contrast, the structural component could reveal differences in returns even if there is no 
discrimination against the disadvantaged groups. For example, an OC and non-OC household might own the same amount of land, but returns would be lower in the nonOC household due to lower quality of the land owned by non-OC households (e.g., no irrigation).

Equation 5 can be reduced to the following different types:

$$
\ln \bar{C}_{O C}-\ln \bar{C}_{N O C}=\left(\bar{X}_{O C}-\bar{X}_{N O C}\right) \beta_{O C}+\bar{X}_{N O C}\left(\beta_{O C}-\beta_{N O C}\right)
$$

This is identical to the standard Blinder-Oaxaca decomposition equation if the function $\mathrm{F}($.) in equation 5 is linear.

$$
\begin{aligned}
\bar{P}_{O C}-\bar{P}_{N O C}= & \sum_{i=1}^{k} W_{\triangle X}^{i}\left[\overline{\left(\overline{\Lambda\left(X_{O C} \beta_{O C}\right.}\right)}-\left(\overline{\Lambda\left(X_{N O C} \beta_{O C}\right.}\right)\right]+ \\
& \sum_{i=1}^{k} W_{\triangle \hat{\beta}}^{i}\left[\overline{\left(\overline{\Lambda\left(X_{N O C} \beta_{O C}\right.}\right)}-\left(\overline{\Lambda\left(X_{N O C} \beta_{N O C}\right.}\right)\right]
\end{aligned}
$$

whereis $\bar{P}$ the average predicted poverty anddenotes a logistic cumulative distribution function.

\section{Decomposition of Change in Poverty Level}

The Blinder-Oaxaca decomposition method used in the present study, along with earlier studies, provides a useful tool for exploring inequality between particular classes of a group, although it does not provide any information on what drives poverty reduction and how poverty reduction differs among groups. The change in poverty inci-

$\mu_{t-1} \quad$ dence in the two time periods can be decomposed into the effects of economic growth and inequality (Datt \& Ravallion 1992; Kakwani 2000; Shorrocks 2013). For instance, poverty would decline in the absence of growth if redistribution took place in favor of the poor. Likewise, even if inequality had not changed over time, economic growth have an impact on poverty. The decomposition of change in the level of poverty is formally expressed as follows:

$$
\begin{aligned}
& \Delta P=P_{t}-P_{t-1}=G+R \\
& G=0.5\left[P\left(\frac{z}{\mu_{t}}, L_{t-1}\right)-P\left(\frac{z}{\mu_{t-1}}, L_{t-1}\right)\right]+0.5\left[P\left(\frac{z}{\mu_{t}}, L_{t}\right)-P\left(\frac{z}{\mu_{t-1}}, L_{t}\right)\right] \\
& R=0.5\left[P\left(\frac{z}{\mu_{t-1}}, L_{t}\right)-P\left(\frac{z}{\mu_{t-1}}, L_{t-1}\right)\right]+0.5\left[P\left(\frac{z}{\mu_{t}}, L_{t}\right)-P\left(\frac{z}{\mu_{t}}, L_{t-1}\right)\right]
\end{aligned}
$$


where $\mathrm{G}$ and $\mathrm{R}$ represent the pure effects of growth and redistribution on poverty respectively, $z$ is poverty line, and $\mu_{t}$ and $L_{t}$ denote the mean income and the Lorenz curve reflecting inequalities at household living standards at period $t$.

The first bracketed equation in the growth component equation indicates the pure effect of economic growth on poverty, inequality at the initial period being held constant, whereas the second bracketed equation reflects pure growth, inequality at the terminal period being held constant. Thus, the growth component is computed by averaging two pure effects of economic growth. The redistribution component is computed in the same way.

\section{RESULTS}

\section{Determinants of Household Consumption}

Table 2 shows selective results of consumption estimations from equation (1) for the determinants of household per capita consumption expenditure in 1999 with village fixed effect.

Table 2. Determinants of Log (consumption) in 1999 with Village Fixed Effects

\begin{tabular}{|c|c|c|c|}
\hline & $\begin{array}{c}\text { All_In } \\
\text { (consumption } \\
\text { per capita) }\end{array}$ & $\begin{array}{c}\text { OC_In } \\
\text { (consumption } \\
\text { per capita) }\end{array}$ & $\begin{array}{l}\text { Non-OC_In } \\
\text { (consumption } \\
\text { per capita) }\end{array}$ \\
\hline $\begin{array}{l}\text { fhead } \\
\text { ( } 1 \text { if household head is female) }\end{array}$ & $\begin{array}{c}0.052 \\
(1.90)^{*}\end{array}$ & $\begin{array}{l}0.056 \\
(0.94)\end{array}$ & $\begin{array}{l}0.03 \\
(1.01)\end{array}$ \\
\hline $\begin{array}{l}\text { age } \\
\text { (age of household head) }\end{array}$ & $\begin{array}{l}-0.008 \\
(3.60)^{\star \star \star}\end{array}$ & $\begin{array}{l}-0.013 \\
(3.06)^{\star \star \star}\end{array}$ & $\begin{array}{l}-0.008 \\
(2.74)^{\star \star \star}\end{array}$ \\
\hline square of age & $\begin{array}{l}0.0001 \\
(3.71)^{\star \star \star}\end{array}$ & $\begin{array}{l}0.0001 \\
(2.77)^{\star \star \star}\end{array}$ & $\begin{array}{l}0.0001 \\
(2.78)^{\star \star \star}\end{array}$ \\
\hline $\begin{array}{l}\text { married } \\
\text { ( } 1 \text { if household head has a spouse) }\end{array}$ & $\begin{array}{l}-0.001 \\
(0.05)\end{array}$ & $\begin{array}{l}0.014 \\
(0.34)\end{array}$ & $\begin{array}{l}-0.012 \\
(0.60)\end{array}$ \\
\hline $\begin{array}{l}\text { primary } \\
\text { ( } 1 \text { if household head completed } \\
\text { primary school) }\end{array}$ & $\begin{array}{l}0.071 \\
(5.38)^{\star \star \star}\end{array}$ & $\begin{array}{l}0.048 \\
(1.79)^{*}\end{array}$ & $\begin{array}{l}0.073 \\
(4.78)^{\star \star \star}\end{array}$ \\
\hline $\begin{array}{l}\text { second } \\
\text { ( } 1 \text { if household head completed } \\
\text { secondary school) }\end{array}$ & $\begin{array}{l}0.135 \\
(9.96)^{* * *}\end{array}$ & $\begin{array}{l}0.141 \\
(5.30)^{\star \star \star}\end{array}$ & $\begin{array}{l}0.116 \\
(6.84)^{* * *}\end{array}$ \\
\hline $\begin{array}{l}\text { upper second } \\
\text { ( } 1 \text { if household head completed } \\
\text { upper secondary school) }\end{array}$ & $\begin{array}{l}0.245 \\
(7.91)^{\star * \star}\end{array}$ & $\begin{array}{l}0.19 \\
(4.12)^{\star \star \star}\end{array}$ & $\begin{array}{l}0.252 \\
(6.38)^{\star \star \star}\end{array}$ \\
\hline
\end{tabular}




\begin{tabular}{|c|c|c|c|}
\hline & $\begin{array}{c}\text { All_In } \\
\text { (consumption } \\
\text { per capita) }\end{array}$ & $\begin{array}{c}\text { OC_In } \\
\text { (consumption } \\
\text { per capita) }\end{array}$ & $\begin{array}{l}\text { Non-OC_In } \\
\text { (consumption } \\
\text { per capita) }\end{array}$ \\
\hline $\begin{array}{l}\text { higher } \\
\text { ( } 1 \text { if household head completed } \\
\text { university or master) }\end{array}$ & $\begin{array}{c}0.368 \\
(11.33)^{\star \star \star}\end{array}$ & $\begin{array}{l}0.401 \\
(9.20)^{\star \star \star}\end{array}$ & $\begin{array}{l}0.311 \\
(7.95)^{\star \star \star}\end{array}$ \\
\hline $\begin{array}{l}\text { female share } \\
\text { (share of female members } \\
\text { in household) }\end{array}$ & $\begin{array}{l}-0.791 \\
(5.11)^{\star \star \star}\end{array}$ & $\begin{array}{l}-1.047 \\
(3.50)^{\star \star \star}\end{array}$ & $\begin{array}{l}-0.654 \\
(3.46)^{\star \star \star}\end{array}$ \\
\hline square of female share & $\begin{array}{l}0.699 \\
(4.41)^{\star \star \star}\end{array}$ & $\begin{array}{l}0.965 \\
(3.20)^{\star \star \star}\end{array}$ & $\begin{array}{l}0.557 \\
(2.88)^{\star \star \star}\end{array}$ \\
\hline $\begin{array}{l}\text { dependency } \\
\text { (dependency ratio of household) }\end{array}$ & $\begin{array}{c}-0.384 \\
(14.02)^{\star \star \star}\end{array}$ & $\begin{array}{l}-0.282 \\
(6.08)^{\star \star \star}\end{array}$ & $\begin{array}{l}-0.412 \\
(13.34)^{\star \star \star}\end{array}$ \\
\hline $\begin{array}{l}\mathrm{OC} \\
\text { ( } 1 \text { if a household belongs to } \mathrm{OC} \text { ) }\end{array}$ & $\begin{array}{l}0.049 \\
(3.26)^{\star * \star}\end{array}$ & - & - \\
\hline $\begin{array}{l}\text { Hindu } \\
\text { ( } 1 \text { if household identifies as Hindu) }\end{array}$ & $\begin{array}{l}0.053 \\
(2.15)^{\star \star}\end{array}$ & $\begin{array}{c}0.068 \\
(1.31)\end{array}$ & $\begin{array}{c}0.04 \\
(1.51)\end{array}$ \\
\hline $\begin{array}{l}\text { land } \\
\text { (the size of land holdings } \\
\text { by household in acres) }\end{array}$ & $\begin{array}{c}0.017 \\
(10.01)^{\star \star \star}\end{array}$ & $\begin{array}{l}0.013 \\
(4.20)^{\star \star \star}\end{array}$ & $\begin{array}{l}0.026 \\
(9.79)^{\star \star \star}\end{array}$ \\
\hline square of land & $\begin{array}{l}-0.0001 \\
(4.43)^{\star \star \star}\end{array}$ & $\begin{array}{l}-0.0004 \\
(2.70)^{\star * \star}\end{array}$ & $\begin{array}{l}-0.0003 \\
(4.60)^{\star * \star}\end{array}$ \\
\hline $\begin{array}{l}\text { pclivestk } \\
\text { (per capita number of livestock) }\end{array}$ & $\begin{array}{c}0.001 \\
(1.17) \\
\end{array}$ & $\begin{array}{c}0.004 \\
(0.26)\end{array}$ & $\begin{array}{c}0.001 \\
(1.02)\end{array}$ \\
\hline $\begin{array}{l}\text { pcproasset } \\
\text { (per capita number } \\
\text { of productive assets) }\end{array}$ & $\begin{array}{c}0.062 \\
(10.29)^{\star * \star}\end{array}$ & $\begin{array}{l}0.066 \\
(7.76)^{\star \star \star}\end{array}$ & $\begin{array}{l}0.056 \\
(7.50)^{\star \star \star}\end{array}$ \\
\hline constant & $\begin{array}{c}8.783 \\
(106.39)\end{array}$ & $\begin{array}{r}9.071 \\
(57.09)\end{array}$ & $\begin{array}{r}8.731 \\
(93.33)\end{array}$ \\
\hline observations & 5,492 & 1,677 & 3,815 \\
\hline R-squared & 0.29 & 0.265 & 0.273 \\
\hline joint significance & $F(17,235)=47.25$ & $F(16,168)=31.91$ & $F(16,231)=36.37$ \\
\hline prob $>F$ & 0.0000 & 0.0000 & 0.0000 \\
\hline
\end{tabular}

Robust t-statistics in parentheses; ${ }^{* *} p<0.01,{ }^{* *} p<0.05,{ }^{*} p<0.1$.

Source: REDS 1999.

A similar pattern obtains for $\mathrm{OC}$ and the non-OC households. For example, a household's per capita consumption expenditure tends to increase, as expected, the more educated the head of the household was and the more land and productive a household own, and these variables are statistically significant for both groups. Female headship is associated positively with household consumption but insignificant for 
both groups. In contrast, a higher dependency burden, that is, the share of family members below 15 or above 65 is negatively associated with per capita consumption. The negative and the positive signs of the female share and its square terms respectively, both strongly significant, suggest a nonlinear effect of gender on household per capital consumption decision making. the higher share of female members within a household, the lower consumption expenditure is likely to be: the marginal effect at mean of the female share $(0.473)$ is $-0.13 \%$, that is, a $1 \%$ increase in the female share tends to reduce household per capita consumption by $0.13 \%$. However, household per capita expenditure rebounds at the female ratio of 0.567 as a threshold. In case of land holdings, although we find the statistically significant hump-shaped nonlinear effect where per capital consumption peaks at 119 acres, or 48 hectares, this result has fewer economic implications for rural India, as the majority of households are small-scale farmers who own less than 2 hectares of land.

Table 3 offers the estimation results obtained from the data for 2006, with village fixed effects.

Table 3. Determinants of Log (consumption) in 2006 with Village Fixed Effects

\begin{tabular}{|c|c|c|c|}
\hline & $\begin{array}{c}\text { All_In } \\
\text { (consumption per capita) }\end{array}$ & $\begin{array}{c}\text { OC_In } \\
\text { (consumption per capita) }\end{array}$ & $\begin{array}{c}\text { Non-OC_In } \\
\text { (consumption per capita) }\end{array}$ \\
\hline fhead & $\begin{array}{l}0.145 \\
(5.95)^{\star * \star}\end{array}$ & $\begin{array}{l}0.189 \\
(4.78)^{\star * \star}\end{array}$ & $\begin{array}{l}0.119 \\
(3.62)^{\star * *}\end{array}$ \\
\hline age & $\begin{array}{l}-0.004 \\
(1.37)\end{array}$ & $\begin{array}{l}-0.009 \\
(1.62)\end{array}$ & $\begin{array}{l}-0.005 \\
(1.48)\end{array}$ \\
\hline square of age & $\begin{array}{c}0.0001 \\
(2.93)^{\star \star \star}\end{array}$ & $\begin{array}{r}0.0001 \\
(2.45)^{\star \star}\end{array}$ & $\begin{array}{c}0.0001 \\
(2.68)^{\star \star \star}\end{array}$ \\
\hline married & $\begin{array}{l}0.066 \\
(3.55)^{\star \star \star}\end{array}$ & $\begin{array}{l}0.117 \\
(3.42)^{\star \star \star}\end{array}$ & $\begin{array}{c}0.049 \\
(2.03)^{\star \star}\end{array}$ \\
\hline primary & $\begin{array}{l}0.061 \\
(3.89)^{\star \star \star}\end{array}$ & $\begin{array}{l}0.038 \\
(1.42)\end{array}$ & $\begin{array}{l}0.059 \\
(3.25)^{\star * \star}\end{array}$ \\
\hline second & $\begin{array}{l}0.135 \\
(7.11)^{\star * \star}\end{array}$ & $\begin{array}{l}0.129 \\
(4.11)^{\star * *}\end{array}$ & $\begin{array}{l}0.119 \\
(5.25)^{\star * \star}\end{array}$ \\
\hline upper second & $\begin{array}{c}0.249 \\
(9.40)^{\star \star \star}\end{array}$ & $\begin{array}{l}0.195 \\
(4.27)^{\star \star *}\end{array}$ & $\begin{array}{l}0.266 \\
(8.51)^{\star \star \star}\end{array}$ \\
\hline higher & $\begin{array}{c}0.34 \\
(11.87)^{\star \star \star}\end{array}$ & $\begin{array}{l}0.309 \\
(7.44)^{\star * *}\end{array}$ & $\begin{array}{l}0.328 \\
(8.97)^{\star * *}\end{array}$ \\
\hline female share & $\begin{array}{l}-0.205 \\
(1.29)\end{array}$ & $\begin{array}{l}-0.523 \\
(1.61)\end{array}$ & $\begin{array}{l}-0.104 \\
(0.59)\end{array}$ \\
\hline $\begin{array}{l}\text { square of } \\
\text { female share }\end{array}$ & $\begin{array}{c}0.186 \\
(1.24)\end{array}$ & $\begin{array}{c}0.482 \\
(1.58)\end{array}$ & $\begin{array}{l}0.098 \\
(0.60)\end{array}$ \\
\hline
\end{tabular}




\begin{tabular}{|c|c|c|c|}
\hline & $\begin{array}{c}\text { All_In } \\
\text { (consumption per capita) }\end{array}$ & $\begin{array}{c}\text { OC_In } \\
\text { (consumption per capita) }\end{array}$ & $\begin{array}{c}\text { Non-OC_In } \\
\text { (consumption per capita) }\end{array}$ \\
\hline dependency & $\begin{array}{l}-0.318 \\
(11.80)^{\star \star \star}\end{array}$ & $\begin{array}{l}-0.327 \\
(6.53)^{\star \star \star}\end{array}$ & $\begin{array}{l}-0.303 \\
(10.32)^{\star \star \star}\end{array}$ \\
\hline OC & $\begin{array}{l}0.14 \\
(6.76)^{\star \star \star}\end{array}$ & - & - \\
\hline Hindu & $\begin{array}{l}0.025 \\
(0.89)\end{array}$ & $\begin{array}{l}0.008 \\
(0.19)\end{array}$ & $\begin{array}{l}0.023 \\
(0.68)\end{array}$ \\
\hline land & $\begin{array}{c}0.003 \\
(1.34)\end{array}$ & $\begin{array}{l}0.006 \\
(1.80)^{*}\end{array}$ & $\begin{array}{c}0.001 \\
(0.40) \\
\end{array}$ \\
\hline square of land & $\begin{array}{l}-0.0001 \\
(2.21)^{\star \star}\end{array}$ & $\begin{array}{l}-0.0001 \\
(2.42)^{\star \star}\end{array}$ & $\begin{array}{l}-0.0004 \\
(0.32)\end{array}$ \\
\hline pclivestk & $\begin{array}{l}0.022 \\
(2.58)^{* *}\end{array}$ & $\begin{array}{l}0.046 \\
(2.31)^{* *}\end{array}$ & $\begin{array}{l}0.015 \\
(1.61)\end{array}$ \\
\hline pcproasset & $\begin{array}{l}0.077 \\
(8.62)^{\star * \star}\end{array}$ & $\begin{array}{l}0.065 \\
(4.43)^{\star \star \star}\end{array}$ & $\begin{array}{l}0.08 \\
(7.25)^{\star \star \star}\end{array}$ \\
\hline constant & $\begin{array}{r}8.381 \\
(87.95)\end{array}$ & $\begin{array}{c}8.763 \\
(45.49)\end{array}$ & $\begin{array}{c}8.386 \\
(77.64)\end{array}$ \\
\hline observations & 5,418 & 1,663 & 3,755 \\
\hline R-squared & 0.265 & 0.222 & 0.233 \\
\hline $\begin{array}{l}\text { joint } \\
\text { significance }\end{array}$ & $F(17,237)=109.62$ & $F(16,170)=1117.13$ & $F(16,232)=29.32$ \\
\hline prob > F & 0.0000 & 0.0000 & 0.0000 \\
\hline
\end{tabular}

Robust t-statistics in parentheses; ${ }^{\star \star \star} p<0.01,{ }^{\star \star} p<0.05,{ }^{*} p<0.1$.

Source: REDS 2006.

Significant determinants for both groups that have a positive effect on household consumption are female headship, having a spouse, higher education, and owning more productive assets. A higher dependency burden tends to lower household consumption for both groups. Larger land holdings and having more livestock are positively associated with household consumption in the OC households, but they are insignificant for the non-OC group.

\section{The Determinants of Poverty}

The results of poverty regression are sensitive to the choice of the poverty cutoff line, which is an arbitrary threshold of household living standards: estimations were carried out using $100 \%$ of rural India's official state consumption poverty line and $120 \%$ and $80 \%$ as extra exercises (that is, the dichotomous dependent variable indicating 
whether a household is consumption poor or not was created using $80 \%, 100 \%$ and $120 \%$ of the official poverty line). Table 4 shows the results from running the conditional fixed-effects logit model with village fixed effects. As the dependent variables indicate poverty status, the signs of most coefficient estimates are opposite from those of consumption estimations.

Table 4. Determinants of Poverty in 1999: Conditional Fixed-Effects Logit with Village Fixed Effects

\begin{tabular}{|c|c|c|c|c|c|c|c|c|c|}
\hline & \multicolumn{3}{|c|}{ All } & \multicolumn{3}{|c|}{$O C$} & \multicolumn{3}{|c|}{ Non-OC } \\
\hline & $\begin{array}{l}\text { Poverty } \\
100\end{array}$ & $\begin{array}{l}\text { Poverty } \\
120\end{array}$ & $\begin{array}{l}\text { Poverty } \\
80\end{array}$ & $\begin{array}{l}\text { Poverty } \\
100\end{array}$ & $\begin{array}{l}\text { Poverty } \\
120\end{array}$ & $\begin{array}{l}\text { Poverty } \\
80\end{array}$ & $\begin{array}{l}\text { Poverty } \\
100\end{array}$ & \begin{tabular}{|c} 
Poverty \\
120
\end{tabular} & $\begin{array}{l}\text { Poverty } \\
80\end{array}$ \\
\hline fhead & $\begin{array}{l}-0.117 \\
(0.49)\end{array}$ & $\begin{array}{l}-0.427 \\
(1.91)^{*}\end{array}$ & $\begin{array}{r}0.207 \\
(0.68)\end{array}$ & $\begin{array}{l}-0.406 \\
(0.79)\end{array}$ & $\begin{array}{l}-0.41 \\
(0.95)\end{array}$ & $\begin{array}{l}0.043 \\
(0.07)\end{array}$ & $\begin{array}{c}0.014 \\
(0.05)\end{array}$ & $\begin{array}{l}-0.345 \\
(1.25)\end{array}$ & $\begin{array}{c}0.264 \\
(0.71)\end{array}$ \\
\hline age & $\begin{array}{c}0.074 \\
(3.62)^{\star * \star}\end{array}$ & $\begin{array}{c}0.109 \\
(5.51)^{\star \star *}\end{array}$ & $\begin{array}{c}0.034 \\
(1.37)\end{array}$ & $\begin{array}{c}0.142 \\
(2.82)^{\star \star \star}\end{array}$ & $\begin{array}{c}0.179 \\
(4.41)^{\star \star \star}\end{array}$ & $\begin{array}{c}0.121 \\
(1.65)^{*}\end{array}$ & $\begin{array}{c}0.063 \\
(2.62)^{\star * \star}\end{array}$ & $\begin{array}{c}0.091 \\
(3.73)^{\star \star \star}\end{array}$ & $\begin{array}{c}0.01 \\
(0.36)\end{array}$ \\
\hline square of age & $\begin{array}{l}-0.001 \\
(3.38)^{\star \star \star}\end{array}$ & $\begin{array}{l}-0.001 \\
(5.33)^{* \star *}\end{array}$ & $\begin{array}{l}-0.0003 \\
(1.35)\end{array}$ & $\begin{array}{l}-0.001 \\
(2.90)^{\star \star \star}\end{array}$ & $\begin{array}{l}-0.002 \\
(4.10)^{\star \star \star}\end{array}$ & \begin{tabular}{|l|}
-0.001 \\
$(1.48)$
\end{tabular} & $\begin{array}{l}-0.001 \\
(2.29)^{\star *}\end{array}$ & $\begin{array}{l}-0.001 \\
(3.61)^{\star * \star}\end{array}$ & $\begin{array}{l}-0.0001 \\
(0.32)\end{array}$ \\
\hline married & $\begin{array}{l}0.205 \\
(1.20)\end{array}$ & $\begin{array}{l}-0.009 \\
(0.05)\end{array}$ & $\begin{array}{l}0.292 \\
(1.35)\end{array}$ & $\begin{array}{l}0.458 \\
(1.25)\end{array}$ & $\begin{array}{c}0.15 \\
(0.46)\end{array}$ & $\begin{array}{l}-0.038 \\
(0.09)\end{array}$ & $\begin{array}{c}0.183 \\
(0.89)\end{array}$ & $\begin{array}{l}0.029 \\
(0.14)\end{array}$ & $\begin{array}{c}0.458 \\
(1.76)^{\star}\end{array}$ \\
\hline primary & $\begin{array}{l}-0.344 \\
(3.07)^{\star \star \star}\end{array}$ & $\begin{array}{l}-0.718 \\
(6.61)^{\star \star *}\end{array}$ & $\begin{array}{l}-0.251 \\
(1.85)^{\star}\end{array}$ & $\begin{array}{l}-0.428 \\
(1.62)\end{array}$ & $\begin{array}{l}-0.634 \\
(2.68)^{* \star \star}\end{array}$ & $\begin{array}{l}-0.551 \\
(1.67)^{\star}\end{array}$ & $\begin{array}{l}-0.244 \\
(1.90)^{*}\end{array}$ & $\begin{array}{l}-0.727 \\
(5.61)^{\star \star \star}\end{array}$ & $\begin{array}{l}-0.181 \\
(1.17)\end{array}$ \\
\hline second & $\begin{array}{l}-0.794 \\
(6.95)^{\star \star \star}\end{array}$ & $\begin{array}{l}-0.972 \\
(9.10)^{\star \star *}\end{array}$ & $\begin{array}{l}-0.727 \\
(5.02)^{\star \star \star}\end{array}$ & $\begin{array}{l}-1.201 \\
(4.67)^{\star \star \star}\end{array}$ & $\begin{array}{l}-0.808 \\
(3.69)^{\star \star \star}\end{array}$ & $\begin{array}{l}-0.918 \\
(2.71)^{* \star *}\end{array}$ & $\begin{array}{l}-0.688 \\
(5.11)^{\star \star \star}\end{array}$ & $\begin{array}{l}-1.036 \\
(7.86)^{* \star *}\end{array}$ & $\begin{array}{l}-0.693 \\
(4.13)^{\star \star \star}\end{array}$ \\
\hline upper second & $\begin{array}{l}-1.274 \\
(5.28)^{* * \star}\end{array}$ & $\begin{array}{l}-1.615 \\
(7.52)^{\star \star \star}\end{array}$ & $\begin{array}{l}-1.031 \\
(3.13)^{\star \star \star}\end{array}$ & $\begin{array}{l}-1.498 \\
(2.92)^{* \star *}\end{array}$ & $\begin{array}{l}-0.988 \\
(2.41)^{* \star}\end{array}$ & $\begin{array}{l}-0.353 \\
(0.54)\end{array}$ & $\begin{array}{l}-1.266 \\
(4.36)^{\star * \star}\end{array}$ & $\begin{array}{l}-1.933 \\
(7.36)^{* \star *}\end{array}$ & $\begin{array}{l}-1.199 \\
(2.93)^{\star \star *}\end{array}$ \\
\hline higher & $\begin{array}{l}-1.719 \\
(5.60)^{\star \star \star}\end{array}$ & $\begin{array}{l}-2.264 \\
(8.12)^{\star \star *}\end{array}$ & $\begin{array}{l}-1.423 \\
(3.13)^{\star \star \star}\end{array}$ & $\begin{array}{l}-2.731 \\
(3.81)^{* * *}\end{array}$ & $\begin{array}{l}-2.834 \\
(4.35)^{\star \star \star}\end{array}$ & $\begin{array}{l}-1.378 \\
(1.54)\end{array}$ & $\begin{array}{l}-1.444 \\
(4.08)^{\star \star \star}\end{array}$ & $\begin{array}{l}-2.133 \\
(6.43)^{\star \star \star}\end{array}$ & $\begin{array}{l}-1.281 \\
(2.34)^{\star \star}\end{array}$ \\
\hline female share & $\begin{array}{l}5.482 \\
(4.12)^{\star * \star}\end{array}$ & $\begin{array}{c}6.111 \\
(5.05)^{\star \star \star}\end{array}$ & $\begin{array}{c}4.444 \\
(2.58)^{\star \star \star}\end{array}$ & $\begin{array}{c}0.122 \\
(0.04)\end{array}$ & $\begin{array}{l}8.575 \\
(3.14)^{\star \star \star}\end{array}$ & $\begin{array}{l}-1.098 \\
(0.27)\end{array}$ & $\begin{array}{l}6.766 \\
(4.41)^{\star \star \star}\end{array}$ & $\begin{array}{l}6.372 \\
(4.46)^{\star \star \star}\end{array}$ & $\begin{array}{l}4.814 \\
(2.44)^{\star \star}\end{array}$ \\
\hline $\begin{array}{l}\text { square of } \\
\text { female share }\end{array}$ & $\begin{array}{l}-4.668 \\
(3.57)^{\star \star \star}\end{array}$ & $\begin{array}{l}-5.361 \\
(4.54)^{\star \star *}\end{array}$ & $\begin{array}{l}-3.916 \\
(2.31)^{* *}\end{array}$ & $\begin{array}{l}0.748 \\
(0.26)\end{array}$ & $\begin{array}{l}-7.513 \\
(2.82)^{\star \star \star}\end{array}$ & $\begin{array}{l}1.748 \\
(0.44)\end{array}$ & $\begin{array}{l}-5.995 \\
(3.99)^{\star \star \star}\end{array}$ & $\begin{array}{l}-5.714 \\
(4.11)^{* \star \star}\end{array}$ & $\begin{array}{l}-4.299 \\
(2.20)^{* *}\end{array}$ \\
\hline dependency & $\begin{array}{c}2.648 \\
(12.33)^{\star \star \star}\end{array}$ & $\begin{array}{c}2.856 \\
(14.08)^{\star \star \star}\end{array}$ & $\begin{array}{c}2.369 \\
(8.76)^{\star \star \star}\end{array}$ & $\begin{array}{c}1.965 \\
(3.94)^{\star \star \star}\end{array}$ & $\begin{array}{c}2.072 \\
(5.00)^{\star \star \star}\end{array}$ & $\begin{array}{c}1.814 \\
(2.65)^{\star \star \star}\end{array}$ & $\begin{array}{c}2.874 \\
(11.52)^{\star \star \star}\end{array}$ & $\begin{array}{c}3.162 \\
(12.94)^{* \star \star}\end{array}$ & $\begin{array}{l}2.487 \\
(8.07)^{\star \star \star}\end{array}$ \\
\hline OC & $\begin{array}{l}-0.324 \\
(2.77)^{\star \star \star}\end{array}$ & $\begin{array}{l}-0.289 \\
(2.63)^{\star \star \star}\end{array}$ & \begin{tabular}{|l|}
-0.081 \\
$(0.55)$
\end{tabular} & - & - & - & - & - & - \\
\hline Hindu & $\begin{array}{l}-0.663 \\
(3.54)^{* \star \star}\end{array}$ & $\begin{array}{l}-0.588 \\
(3.14)^{\star \star \star}\end{array}$ & $\begin{array}{l}-0.511 \\
(2.43)^{* \star}\end{array}$ & $\begin{array}{l}-0.774 \\
(1.70)^{*}\end{array}$ & $\begin{array}{l}-0.594 \\
(1.49)\end{array}$ & $\begin{array}{l}-1.645 \\
(2.58)^{\star \star \star}\end{array}$ & $\begin{array}{l}-0.477 \\
(1.93)^{\star}\end{array}$ & $\begin{array}{l}-0.477 \\
(1.85)^{*}\end{array}$ & $\begin{array}{l}-0.376 \\
(1.32)\end{array}$ \\
\hline land & $\begin{array}{l}-0.137 \\
(9.95)^{\star \star \star}\end{array}$ & $\begin{array}{c}-0.151 \\
(12.52)^{\star \star *}\end{array}$ & $\begin{array}{l}-0.128 \\
(6.72)^{\star \star \star}\end{array}$ & $\begin{array}{l}-0.142 \\
(4.80)^{\star \star \star}\end{array}$ & $\begin{array}{l}-0.143 \\
(6.08)^{\star * *}\end{array}$ & $\begin{array}{l}-0.189 \\
(4.06)^{\star \star \star}\end{array}$ & $\begin{array}{l}-0.162 \\
(8.17)^{\star \star \star}\end{array}$ & $\begin{array}{c}-0.189 \\
(10.33)^{* * *}\end{array}$ & $\begin{array}{l}-0.143 \\
(4.87)^{\star \star \star}\end{array}$ \\
\hline
\end{tabular}




\begin{tabular}{|c|c|c|c|c|c|c|c|c|c|}
\hline & \multicolumn{3}{|c|}{ All } & \multicolumn{3}{|c|}{$\mathrm{OC}$} & \multicolumn{3}{|c|}{ Non-OC } \\
\hline & $\begin{array}{c}\text { Poverty } \\
100\end{array}$ & $\begin{array}{c}\text { Poverty } \\
120\end{array}$ & $\begin{array}{c}\text { Poverty } \\
80\end{array}$ & $\begin{array}{l}\text { Poverty } \\
100\end{array}$ & $\begin{array}{c}\text { Poverty } \\
120\end{array}$ & $\begin{array}{c}\text { Poverty } \\
80\end{array}$ & $\begin{array}{c}\text { Poverty } \\
100\end{array}$ & $\begin{array}{c}\text { Poverty } \\
120\end{array}$ & $\begin{array}{l}\text { Poverty } \\
80\end{array}$ \\
\hline square of land & $\begin{array}{c}0.001 \\
(6.01)^{\star \star \star}\end{array}$ & $* \begin{array}{c}0.001 \\
(7.51)^{\star \star \star}\end{array}$ & $\begin{array}{c}0.001 \\
(4.12)^{\star \star \star}\end{array}$ & $\begin{array}{c}0.001 \\
(2.64)^{\star \star *}\end{array}$ & & & & & \\
\hline pclivestk & & & & & & & & & \\
\hline pcproasset & $\begin{array}{l}-0.386 \\
(9.29)^{* * *}\end{array}$ & $\begin{array}{c}\mid-0.384 \\
(10.80)^{* * *}\end{array}$ & $\begin{array}{l}-0.441 \\
(7.01)^{\star \star \star}\end{array}$ & $\begin{array}{l}-0.467 \\
(4.69)^{* * *}\end{array}$ & $\begin{array}{l}-0.39 \\
(5.21)^{\star * *}\end{array}$ & & $\begin{array}{l}-0.342 \\
(7.09)^{\star \star \star}\end{array}$ & & \\
\hline observations & 4,817 & 5,105 & 3,592 & 941 & 1,217 & 649 & 3,396 & 3,545 & 2,600 \\
\hline $\begin{array}{l}\text { joint } \\
\text { significance }\end{array}$ & $\begin{array}{c}\text { LR chi2 } \\
(17) \\
=708.32\end{array}$ & $\begin{array}{c}\text { LR chi2 } \\
(17) \\
=988.43\end{array}$ & \begin{tabular}{|c|} 
LR chi2 \\
$(17)$ \\
$=358.48$
\end{tabular} & $\begin{array}{c}\begin{array}{c}\text { LR chi2 } \\
(16) \\
=151.45\end{array}\end{array}$ & \begin{tabular}{|c|} 
LR chi2 \\
$(16)$ \\
$=215.40$
\end{tabular} & $\begin{array}{c}\text { LR chi² } \\
(16) \\
=79.62\end{array}$ & $\begin{array}{c}\begin{array}{c}\text { LR } \text { chi }^{2} \\
(16) \\
=478.66\end{array}\end{array}$ & $\begin{array}{c}\text { LR chi2 } \\
(16) \\
=690.94\end{array}$ & $\begin{array}{c}\text { LR chi² } \\
(16) \\
=275.83\end{array}$ \\
\hline prob. > chi² & 0.0000 & 0.0000 & 0.0000 & 0.0000 & 0.0000 & 0.0000 & 0.0000 & 0.0000 & 0.0000 \\
\hline
\end{tabular}

z-statistics in parentheses; ${ }^{* * *} p<0.01,{ }^{* *} p<0.05,{ }^{*} p<0.1$.

Source: REDS 1999.

While female headship tends to reduce the probability of poverty for both groups, age and the square of age is found to be significant for the non-OC group only. Having a spouse is likely to reduce poverty among the non-OC groups at $100 \%$ of the poverty line, but it is insignificant at $80 \%$ of the poverty line for both non-OC and OC households.

For the OC households, education above the upper secondary level has a negative and significant effect on poverty (at $100 \%$ and $120 \%$ of the poverty line). For the nonOC households, most of the coefficient estimates of educational dummies have negative and significant poverty-reducing effects. The dependency ratio is positively associated with the probability of poverty for both groups and is significant in all cases. Having more productive assets is observed to reduce poverty, whereas the poverty-reducing effect of land is found to be significant for the OC households only at $100 \%$ and $120 \%$ of the poverty line.

Table 5 provides the results of poverty estimations obtained using the 2006 data. 
Table 5. Determinants of Poverty in 2006: Conditional Fixed-Effects Logit with Village Fixed Effects

\begin{tabular}{|c|c|c|c|c|c|c|c|c|c|}
\hline & \multicolumn{3}{|c|}{ All } & \multicolumn{3}{|c|}{ OC } & \multicolumn{3}{|c|}{ Non-OC } \\
\hline & $\begin{array}{c}\text { Poverty } \\
100\end{array}$ & $\begin{array}{c}\text { Poverty } \\
120\end{array}$ & $\begin{array}{l}\text { Poverty } \\
80\end{array}$ & $\begin{array}{l}\text { Poverty } \\
100\end{array}$ & $\begin{array}{c}\text { Poverty } \\
120\end{array}$ & $\begin{array}{l}\text { Poverty } \\
80\end{array}$ & $\begin{array}{l}\text { Poverty } \\
100\end{array}$ & $\begin{array}{c}\text { Poverty } \\
120\end{array}$ & $\begin{array}{l}\text { Poverty } \\
80\end{array}$ \\
\hline fhead & $\begin{array}{l}-0.873 \\
(4.32)^{\star \star \star}\end{array}$ & $\begin{array}{l}-0.687 \\
(3.86)^{\star \star \star}\end{array}$ & \begin{tabular}{|l|}
-0.916 \\
$(3.51)^{\star \star \star}$
\end{tabular} & $\begin{array}{l}-1.022 \\
(2.26)^{\star \star}\end{array}$ & $\begin{array}{l}-0.987 \\
(2.72)^{\star \star \star *}\end{array}$ & $\begin{array}{l}-1.375 \\
(1.92)^{*}\end{array}$ & $\begin{array}{l}-0.852 \\
(3.60)^{\star \star \star}\end{array}$ & $\begin{array}{l}-0.588 \\
(2.76)^{\star \star \star}\end{array}$ & $\begin{array}{l}-0.702 \\
(2.37)^{\star \star}\end{array}$ \\
\hline age & $\begin{array}{c}0.066 \\
(2.91)^{\star \star \star}\end{array}$ & $\begin{array}{c}0.045 \\
(2.27)^{\star \star} \\
\end{array}$ & $\begin{array}{c}0.031 \\
(1.10) \\
\end{array}$ & $\begin{array}{l}0.043 \\
(0.74)\end{array}$ & $\begin{array}{c}0.018 \\
(0.39)\end{array}$ & $\begin{array}{c}0.014 \\
(0.18)\end{array}$ & $\begin{array}{c}0.085 \\
(3.31)^{\star \star \star}\end{array}$ & $\begin{array}{c}0.064 \\
(2.76)^{\star \star \star}\end{array}$ & $\begin{array}{c}0.052 \\
(1.66)^{*}\end{array}$ \\
\hline square of age & $\begin{array}{l}-0.001 \\
(3.63)^{\star \star \star}\end{array}$ & $\begin{array}{l}-0.001 \\
(3.31)^{\star * \star}\end{array}$ & $\begin{array}{l}-0.0001 \\
(1.69)^{*}\end{array}$ & $\begin{array}{l}-0.0005 \\
(0.79)\end{array}$ & $\begin{array}{l}-0.0003 \\
(0.81)\end{array}$ & $\begin{array}{l}-0.0002 \\
(0.27)\end{array}$ & $\begin{array}{l}-0.001 \\
(3.99)^{\star \star \star}\end{array}$ & $\begin{array}{l}-0.001 \\
(3.57)^{\star \star \star}\end{array}$ & $\begin{array}{l}-0.001 \\
(2.12)^{\star *}\end{array}$ \\
\hline married & $\begin{array}{l}-0.449 \\
(2.69)^{\star \star \star}\end{array}$ & $\begin{array}{l}-0.361 \\
(2.44)^{\star *}\end{array}$ & $\begin{array}{l}-0.353 \\
(1.64)\end{array}$ & $\begin{array}{l}-0.166 \\
(0.42)\end{array}$ & $\begin{array}{l}-0.343 \\
(1.10)\end{array}$ & $\begin{array}{l}-0.491 \\
(0.93)\end{array}$ & $\begin{array}{l}-0.574 \\
(2.93)^{\star \star \star}\end{array}$ & $\begin{array}{l}-0.358 \\
(1.99)^{\star *}\end{array}$ & $\begin{array}{l}-0.329 \\
(1.32)\end{array}$ \\
\hline primary & $\begin{array}{l}-0.293 \\
(2.51)^{\star *}\end{array}$ & \begin{tabular}{|l|}
-0.342 \\
$(3.31)^{\star \star \star}$
\end{tabular} & $\begin{array}{l}-0.242 \\
(1.68)^{*}\end{array}$ & $\begin{array}{l}-0.136 \\
(0.53)\end{array}$ & $\begin{array}{l}-0.152 \\
(0.67)\end{array}$ & $\begin{array}{c}0.071 \\
(0.22)\end{array}$ & $\begin{array}{l}-0.325 \\
(2.38)^{\star *}\end{array}$ & $\begin{array}{l}-0.352 \\
(2.90)^{\star \star \star}\end{array}$ & $\begin{array}{l}-0.23 \\
(1.36)\end{array}$ \\
\hline second & $\begin{array}{l}-0.404 \\
(3.25)^{\star \star \star} \\
\end{array}$ & \begin{tabular}{|l|}
-0.618 \\
$(5.60)^{\star \star \star}$
\end{tabular} & $\begin{array}{l}-0.684 \\
(4.16)^{\star \star \star}\end{array}$ & $\begin{array}{l}-0.288 \\
(1.03) \\
\end{array}$ & $\begin{array}{l}-0.55 \\
(2.28)^{\star *}\end{array}$ & $\begin{array}{l}-0.007 \\
(0.02)\end{array}$ & $\begin{array}{l}-0.432 \\
(2.94)^{\star \star \star}\end{array}$ & $\begin{array}{l}-0.562 \\
(4.30)^{\star \star \star}\end{array}$ & $\begin{array}{l}-0.775 \\
(3.98)^{\star \star \star}\end{array}$ \\
\hline upper second & $\begin{array}{l}-1.204 \\
(6.44)^{\star \star \star}\end{array}$ & \begin{tabular}{l|}
-1.247 \\
$(7.97)^{\star * *}$
\end{tabular} & \begin{tabular}{l|}
-1.078 \\
$(4.49)^{\star * \star}$
\end{tabular} & $\begin{array}{l}-0.674 \\
(1.83)^{*}\end{array}$ & $\begin{array}{l}-0.832 \\
(2.70)^{\star * \star}\end{array}$ & $\begin{array}{l}-0.286 \\
(0.63)\end{array}$ & $\begin{array}{l}-1.429 \\
(6.17)^{\star * \star}\end{array}$ & $\begin{array}{l}-1.414 \\
(7.29)^{\star * \star}\end{array}$ & $\begin{array}{l}-1.199 \\
(3.94)^{\star * \star}\end{array}$ \\
\hline higher & $\begin{array}{l}-1.442 \\
(5.90)^{\star \star *}\end{array}$ & \begin{tabular}{|l|}
-1.63 \\
$(8.42)^{\star * \star}$
\end{tabular} & \begin{tabular}{|l|}
-1.578 \\
$(4.55)^{\star * \star}$ \\
\end{tabular} & $\begin{array}{l}-1.279 \\
(2.26)^{\star *}\end{array}$ & $\begin{array}{l}-1.664 \\
(4.02)^{\star \star *}\end{array}$ & $\begin{array}{l}-1.355 \\
(1.58)\end{array}$ & $\begin{array}{l}-1.326 \\
(4.65)^{\star * \star}\end{array}$ & $\begin{array}{l}-1.444 \\
(6.27)^{\star * *}\end{array}$ & $\begin{array}{l}-1.555 \\
(3.76)^{\star * \star}\end{array}$ \\
\hline female share & \begin{tabular}{|l|}
1.301 \\
$(1.01)$ \\
\end{tabular} & $\begin{array}{c}1.916 \\
(1.73)^{\star}\end{array}$ & $\begin{array}{c}1.435 \\
(0.85) \\
\end{array}$ & $\begin{array}{c}1.108 \\
(0.39) \\
\end{array}$ & $\begin{array}{l}6.07 \\
(2.41)^{\star \star}\end{array}$ & $\begin{array}{l}1.759 \\
(0.43) \\
\end{array}$ & $\begin{array}{c}1.536 \\
(1.01) \\
\end{array}$ & $\begin{array}{c}1.244 \\
(0.95) \\
\end{array}$ & $\begin{array}{c}0.218 \\
(0.11) \\
\end{array}$ \\
\hline $\begin{array}{l}\text { square of } \\
\text { female share }\end{array}$ & $\begin{array}{l}-0.725 \\
(0.59) \\
\end{array}$ & \begin{tabular}{|l|}
-1.361 \\
$(1.31)$ \\
\end{tabular} & \begin{tabular}{|l|}
-0.907 \\
$(0.55)$ \\
\end{tabular} & $\begin{array}{c}0.36 \\
(0.14) \\
\end{array}$ & $\begin{array}{l}-4.662 \\
(1.98)^{\star *}\end{array}$ & $\begin{array}{l}-0.631 \\
(0.16)\end{array}$ & $\begin{array}{l}-1.024 \\
(0.71)\end{array}$ & $\begin{array}{l}-0.75 \\
(0.61)\end{array}$ & $\begin{array}{c}0.319 \\
(0.17)\end{array}$ \\
\hline dependency & $\begin{array}{c}2.394 \\
(11.13)^{\star \star \star}\end{array}$ & $\begin{array}{c}1.955 \\
(10.90)^{\star \star \star}\end{array}$ & \begin{tabular}{c|}
2.199 \\
$(7.97)^{\star \star \star}$ \\
\end{tabular} & $\begin{array}{c}1.827 \\
(3.84)^{\star \star \star}\end{array}$ & $\begin{array}{c}2.008 \\
(5.13)^{\star \star \star}\end{array}$ & $\begin{array}{l}2.016 \\
(3.31)^{\star \star \star}\end{array}$ & $\begin{array}{c}2.544 \\
(10.11)^{\star \star \star}\end{array}$ & $\begin{array}{c}1.908 \\
(9.14)^{\star \star \star}\end{array}$ & $\begin{array}{c}2.271 \\
(6.98)^{\star \star \star}\end{array}$ \\
\hline OC & $\begin{array}{l}-0.698 \\
(5.42)^{* \star *}\end{array}$ & \begin{tabular}{|l|}
-0.669 \\
$(6.01)^{* \star *}$
\end{tabular} & \begin{tabular}{|l|}
-0.474 \\
$(2.98)^{* * *}$ \\
\end{tabular} & - & - & - & - & - & - \\
\hline Hindu & $\begin{array}{l}-0.076 \\
(0.41)\end{array}$ & \begin{tabular}{|c|}
-0.177 \\
$(1.03)$
\end{tabular} & $\begin{array}{c}0.512 \\
(2.08)^{\star *}\end{array}$ & $\begin{array}{l}-0.291 \\
(0.72)\end{array}$ & $\begin{array}{l}0.096 \\
(0.28)\end{array}$ & $\begin{array}{c}0.41 \\
(0.69)\end{array}$ & $\begin{array}{c}0.337 \\
(1.23)\end{array}$ & $\begin{array}{l}-0.228 \\
(0.92)\end{array}$ & $\begin{array}{l}0.8 \\
(2.44)^{\star *}\end{array}$ \\
\hline land & $\begin{array}{l}-0.061 \\
(3.03)^{\star \star \star}\end{array}$ & \begin{tabular}{|l|}
-0.035 \\
$(2.26)^{\star \star}$
\end{tabular} & $\begin{array}{l}-0.084 \\
(2.11)^{\star \star}\end{array}$ & $\begin{array}{l}-0.104 \\
(2.47)^{\star *}\end{array}$ & $\begin{array}{l}-0.08 \\
(2.42)^{\star *}\end{array}$ & $\begin{array}{l}-0.078 \\
(0.75)\end{array}$ & $\begin{array}{l}-0.044 \\
(1.42)\end{array}$ & $\begin{array}{l}-0.017 \\
(0.72) \\
\end{array}$ & $\begin{array}{l}-0.07 \\
(1.30)\end{array}$ \\
\hline square of land & $\begin{array}{c}0.001 \\
(3.63)^{\star \star \star}\end{array}$ & $\begin{array}{r}0.0005 \\
(1.99)^{\star *}\end{array}$ & $\begin{array}{l}0.001 \\
(0.65)\end{array}$ & $\begin{array}{c}0.001 \\
(2.57)^{\star \star}\end{array}$ & $\begin{array}{l}0.001 \\
(1.37)\end{array}$ & $\begin{array}{l}-0.001 \\
(0.16)\end{array}$ & $\begin{array}{c}0.001 \\
(0.75)\end{array}$ & $\begin{array}{l}0.0004 \\
(0.53)\end{array}$ & $\begin{array}{c}0.001 \\
(0.29)\end{array}$ \\
\hline pclivestk & $\begin{array}{l}-0.165 \\
(2.22)^{\star *}\end{array}$ & $\begin{array}{l}-0.074 \\
(1.44)\end{array}$ & $\begin{array}{l}-0.037 \\
(0.37)\end{array}$ & $\begin{array}{l}-0.193 \\
(1.02)\end{array}$ & $\begin{array}{l}-0.068 \\
(0.48)\end{array}$ & $\begin{array}{l}-0.116 \\
(0.42)\end{array}$ & $\begin{array}{l}-0.18 \\
(2.14)^{\star \star}\end{array}$ & $\begin{array}{l}-0.077 \\
(1.37)\end{array}$ & $\begin{array}{l}-0.032 \\
(0.29)\end{array}$ \\
\hline pcproasset & $\begin{array}{c}-0.577 \\
(11.77)^{\star \star \star} \\
\end{array}$ & \begin{tabular}{|c|}
-0.57 \\
$(14.48)^{\star \star \star *}$ \\
\end{tabular} & $\begin{array}{l}-0.579 \\
(8.50)^{\star \star \star}\end{array}$ & $\begin{array}{l}-0.366 \\
(3.81)^{\star \star \star}\end{array}$ & $\begin{array}{l}-0.45 \\
(5.77)^{\star \star \star}\end{array}$ & $\begin{array}{l}-0.098 \\
(1.17)\end{array}$ & $\begin{array}{c}-0.642 \\
(10.76)^{\star \star \star} \\
\end{array}$ & $\begin{array}{c}-0.612 \\
(12.64)^{\star \star \star} \\
\end{array}$ & $\begin{array}{l}-0.774 \\
(8.99)^{\star \star \star}\end{array}$ \\
\hline observations & 4,512 & 5,040 & 3,536 & 950 & 1,126 & 584 & 3,091 & 3,475 & 2,426 \\
\hline $\begin{array}{l}\text { joint } \\
\text { significance }\end{array}$ & $\begin{array}{c}\text { LR chi2 }^{2} \\
(17) \\
=633.56\end{array}$ & $\begin{array}{c}\begin{array}{l}\text { LR chi } \\
2 \\
(17) \\
=820.73\end{array}\end{array}$ & 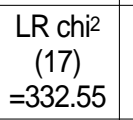 & $\begin{array}{c}\text { LR chi }^{2} \\
(16) \\
=83.53\end{array}$ & $\begin{array}{c}\text { LR chi }^{2} \\
(16) \\
=151.22\end{array}$ & $\begin{array}{c}\text { LR chi }^{2} \\
(16) \\
=31.76\end{array}$ & $\begin{array}{c}\begin{array}{l}\text { LR chi }^{2} \\
(16) \\
=452.65\end{array}\end{array}$ & $\begin{array}{c}\begin{array}{l}\text { LR chi } \\
\\
(16) \\
=\end{array} \\
=524.52\end{array}$ & $\begin{aligned} & \text { LR chi }^{2} \\
& (16) \\
= & 268.49\end{aligned}$ \\
\hline prob. > chi ${ }^{2}$ & 0.0000 & 0.0000 & 0.0000 & 0.0000 & 0.0000 & 0.0000 & 0.0000 & 0.0000 & 0.0000 \\
\hline
\end{tabular}

The Korean Journal of Policy Studies 
The results are in general similar to those obtained from the 1999 data. Higher education level, more productive assets, and lager size of land holdings tend to reduce poverty and are significant variables in most cases across social groups. The effect of the number of livestock owned is negative with respect to poverty, as expected, but is statistically insignificant. For the non-OC households, age and its square are significant, suggesting the nonlinear effect of age of the household head on poverty. Female headship and having a spouse are associated negatively with household poverty.

\section{Decomposition Analysis}

\section{Decomposition of Disparity}

The results of the decomposition analysis of the economic disparity between the OC and the non-OC groups are given in Table 6. The results confirm the findings in the literature (e.g. Kijima 2006; Gang et al. 2008) to the effect that economic disparity as proxied by household per capita consumption and poverty incidence can largely be attributed to the difference in the structural component.

Table 6. Blinder-Oaxaca Decomposition 8

\begin{tabular}{l|c|c|c|c}
\hline Year 1999 & $\log ($ cons) & Poverty 100 & Poverty 120 & Poverty 80 \\
\hline characteristic & 0.174 & -0.106 & -0.117 & -0.07 \\
\hline structural & 0.073 & -0.059 & -0.097 & -0.018 \\
\hline aggregate difference & 0.248 & -0.165 & -0.214 & -0.088 \\
\hline Year 2006 & $\log (\mathrm{cons})$ & Poverty 100 & Poverty 120 & Poverty 80 \\
\hline characteristic & 0.113 & -0.062 & -0.094 & -0.021 \\
\hline structural & 0.153 & -0.056 & -0.072 & -0.041 \\
\hline aggregate difference & 0.266 & -0.118 & -0.165 & -0.062 \\
\hline
\end{tabular}

Note: Decomposition is carried out using Powers, Yoshioka \& Yun 2011. Source: REDS 1999 and 2006.

8. Given that the official poverty line in rural India is set according to per capita minimum expenditure, it is reasonable to use per capita consumption expenditure as an indicator of household living standards, as I do in the present study. When we apply the alternative indicator of consumption expenditure per adult to an adult-equivalent scale that captures economies of scale in household consumption, the findings are similar to those obtained using per capita expenditure. For instance, using consumption expenditure per adult in 
It is useful to note some additional key findings that have not been discussed in earlier studies. First, using data from two time periods, we also find that the relative contribution of the structural component over time in rural India sharply increased from $30 \%$ in 1999 to $57 \%$ in 2006. As we have seen, affirmative action interventions on behalf of the non-OC group might improve the welfare of the group and lift millions of people out of poverty: the rate of poverty reduction in the non-OC group was faster than that of the OC group during the period from 1999- to 2006. However, the structural transformation of the Indian economy in the wake of comprehensive economic reforms such as liberalization and marketization during 1990s may have increased the productivity gap between the two groups and limited the effects of affirmative action programs, which were largely geared toward the public sector.

However, note that our findings do not reveal what aspect of the structural component is responsible for the economic disparity: it could either be the result of widespread discrimination against disadvantaged minorities or the result of differences in the quality of assets (e.g., two households own same amount of land, but one cultivates irrigated land whereas the other has no irrigation). For example, Ashish Singh (2011) argues that low productivity among disadvantaged households stems from discrimination that denies these households access to factor input and output markets and results in the loss of income. In contrast, Raghbendra Jha et al. (2009) might support the opposite view, in light of their findings that a poverty nutrition trap exists in rural India: nutrient intake might differ among individuals due to a difference in the quality of food, even if the same quantities of good are ingested, and this difference in the quality of food influences labor productivity and hence income.

Second, the magnitude of the contribution of the structural component in the decomposition analysis differs depending on whether one uses the welfare indicator or poverty line. Moreover, while the contribution of the structural component decreases from $45.3 \%$ to 43.6 at $120 \%$ of poverty line, it sharply rises at $100 \%$ and $80 \%$ of the poverty lines, which implies that the returns on household assets worsened in poorer households over time. Particular attention ought to be paid to this when public programs are designed to help these disadvantaged groups.

Third, the disparity in consumption among social groups in rural India increased between 1999 and 2006 even though gap with respect to the incidence of poverty declined over the same period.

1999, we find that the contributions of characteristic and structural components are 0.185 and 0.067 respectively, which are comparable with the estimates in table 6 . Full results are available on request. 


\section{Decomposition of Change in the Level of Poverty}

The results from decomposition of change on the level of poverty are given in Table 7.

Table 7. Decomposition of Poverty Change between 1999 and 2006

\begin{tabular}{l|c|c|c|c|c}
\hline & Poverty in 1999 & Poverty in 2006 & Difference & Growth & Redistribution \\
\hline Rural India & 0.308 & 0.249 & -0.058 & -0.084 & 0.028 \\
\hline OC & 0.213 & 0.183 & -0.030 & -0.054 & 0.024 \\
\hline Non-OC & 0.350 & 0.293 & -0.057 & -0.074 & 0.018 \\
\hline SC & 0.376 & 0.289 & -0.087 & -0.082 & -0.004 \\
\hline ST & 0.406 & 0.303 & -0.100 & -0.096 & -0.006 \\
\hline OBC & 0.380 & 0.300 & -0.078 & -0.069 & -0.010 \\
\hline
\end{tabular}

Note: Given that the poverty line is different across states, the estimates are calculated by taking an average of social group decomposition results computed from each of 17 states using Distributive Analysis Stata Package (DASP) software.

Source: REDS 1999 and 2006.

Table 7 indicates that poverty reduction has largely been driven by growth that is proxied here by an increase in mean consumption expenditure. Note that the negative signs of the growth and redistribution components in the fifth and the sixth columns reflect poverty- reducing effects. Hence, the positive sign observed in the redistribution component for rural India implies that worsening inequality offset the positive effect of growth on poverty. For example, although the overall poverty rate in rural India decreased from $30.8 \%$ to $24.9 \%, 5.8 \%$ point change, if inequality had not worsened between 1999 and 2006, economic growth would have reduced the poverty rate it by $8.4 \%$. Although redistribution had a negative impact on poverty reduction among both the $\mathrm{OC}$ and the non-OC groups, the impact was much greater in the OC households: the worsening inequality almost halved the poverty-reducing effect of growth. In contrast, inequality offset the pure growth effect in the non-OC group by only one-fourth. At a disaggregated level, the decomposition results show that poor households in all the disadvantaged groups (SC, ST and OBC) benefited from both economic growth and redistribution. ${ }^{9}$ This is contrasts with the result for the $\mathrm{OC}$ group, for whom

9. The different signs in the redistribution effect found in aggregate and disaggregate levels of the non-OC group might be interpreted as indicating that although redistribution took place within the targeted group, the differing rate of participation in local governance or in affirmative action programs designed for particular castes had a negative effect on poverty 
inequality increased. The positive effect of redistribution might be partly explained by affirmative action programs in India. ${ }^{10}$ Like Pande (2003), Nishith Prakash (2007) and Aimee Chin and Prakash (2011) observe that increasing the share of political reservations in state legislative assemblies has reduced poverty for the STs and that the impact appears to be greater in rural areas than urban areas. At a more local level, Timothy Besley et al. (2004, 2005) and Esther Duflo et al. (2005) find that the identity of leaders at Gram Panchayat matters when it comes to public goods allocation. According to their analysis, assigning pradhan seats to members of the non-OC groups gives targeted groups greater bargaining power and enables them to procure more resources. ${ }^{11}$

\section{CONCLUSION}

The present study examines the factors that determine household consumption expenditure and poverty among OC and non-OC households and investigates why non-OC groups are poorer than OC groups, drawing on India's national representative rural household survey, REDS, for the years 1999 and 2006. It also evaluates poverty reduction by considering the effects of economic growth and inequality on it. Similar patterns obtain with respect to both the determinants of consumption and poverty: household composition (e.g., dependency burden), educational attainment above secondary school, and land are associated with household poverty (negatively) as well as with household consumption (positively). However, there are also differences. For example, household poverty is more likely in the non-OC group if the head of the household has a spouse or has only a primary education, but this is not the case for the OC group. I also find that the household productive assets are strongly associated with

reduction among overall non-OC groups given the much larger size of population. However, note that I only evaluate the effect of redistribution on households that have been divided into poor and nonpoor categories. So the present study does not necessarily suggest that inequality has worsened among the non-OC group in general; that is, the impact of redistribution on the incidence of poverty will vary depending on who among the poor (e.g., the extremely poor or the marginally poor) disproportionately benefits more from redistribution.

10. India's affirmative action programs are basically caste based, though some of them target women. See Deshpande 2013 for an overview of affirmative action in India.

11. Indeed, Besley et al (2004) and Duflo et al (2005) do not directly assess the impact of political reservations on the living standards of the targeted groups such as SC. However, it can be inferred that the increasing provision of local public goods such as public schools, irrigation and sanitation facilities, and so on would have a positive impact on the welfare of the disadvantaged group by increasing labor productivity. 
the level of household per capita consumption and poverty status, while the number of livestock owned is not.

My decomposition analysis of economic disparity confirms that households in the non-OC group are poorer not only because they have fewer assets but also because their assets generate lower returns than the assets of the OC households either because of discrimination against non-OC groups or the low quality of their assets. Furthermore, that the contribution of the structural component to total inequality has increased over time (to $58 \%$ of total consumption inequality) offers an important policy perspective, suggesting that while it is necessary to continue developing programs designed to help non-OC households, it is also essential for the government to attempt to increase the returns on their assets by either improving the quality of their assets or removing the existing discriminations, thereby improving productivity, which in turn will poverty reduction durable. In particular, the influence of the structural component is found to be more significant in poorer households (at $80 \%$ and $100 \%$ of the poverty like vs. $120 \%$ of poverty line). On the other hand, the decomposition analysis of the change in poverty level over the period from 19992006 shows that economic growth would lift more people up from poverty than it did if inequality held constant during the periods. Nevertheless, both the higher economic performance and the positive impact of redistribution on poverty reduction observed in the SC, ST and OBC groups might be a sign that poverty overall is declining.

As far as policy implications go, first, the government needs to continue to eliminate discrimination. Second, in order to properly implement reservation policy, the government should take steps to see that providing quotas for jobs or educational institutions is not end in itself. Not only should the government put an end to formal and informal practices that exclude disadvantaged groups, but it should also provide fertile ground for these groups to benefit from such policy measures. Furthermore, there need to be supplementary measures to strengthen the effectiveness of the current affirmative action programs, since at present there is no monitoring nor are there any penalties for evading such programs (Deshpande 2013). Furthermore, as part of ongoing efforts to eliminate discrimination, the government also needs to increase the productivity of the assets owned by non-OC households. India is a land of small farmers who own less than two hectares of land, and the majority of rural non-OC households are marginalized farmers. ${ }^{12}$ The stagnation of productivity, the decline in food grain production, and hence the increase in food prices together lead to severe food insecurity and malnourishment. South Korea's experience with the agricultural production expansion from

12. For example, the proportion of SC households that own less than half a hectare of land exceeds 50\% (Dev, 2012). 
1968 to 1977 can perhaps offer guidance. The primary objective of South Korea's agricultural policy was to achieve self-sufficiency in rice production. In order to increase food production using modern processes, the government developed and disseminated agricultural technologies, provided guidance to farming villages, developed agricultural water resources and improved the quality of seeds, and created various production organizations so that famers could collaborate in farming and farm management. As a result, South Korea achieved self-sufficiency of rice production by 1977 (Kim, 2015). Easy access to irrigation systems and water resources in dry land areas, better and expanded agricultural research centers, and support for collaboration through production organizations considering the generally small amount of land owned by rural Indian farmers might help productivity among non-OC groups.

\section{REFERENCES}

Anand, R., Tulin, V., \& Kumar, N. 2014. India: Defining and explaining inclusive growth and poverty reduction. IMF Working Paper WP/14/63, International Monetary Fund, Washington, DC.

Besley, T., Rahman, L., Pande, R., \& Rao, V. 2004. The politics of public good provision: Evidence from Indian local governments. Journal of the European Economic Association, 2(2): 416-426.

Besley, T., Rahman, L., Pande, R., \& Rao, V. 2005. Participatory democracy in action: Survey evidence from south India. Journal of European Economic Association, 3(2): 648-657.

Bhaumik, S. K., \& Chakrabarty, M. 2006. Earnings inequality in India: Has the rise of caste and religion based politics in India had an impact? IZA Discussion Paper Series No. 2008, Institute for the Study of Labor, Bonn.

Blair, H. 2000. Participation and accountability at the periphery: Democratic local government In six countries. World Development, 28(1): 21-39.

Blinder, A. S. 1973. Wage discrimination: Reduced form and structural estimates. Journal of Human Resources, 8(4): 436-455.

Binswanger, H., \& Sillers, D. A. 1983. Risk aversion and credit constraint in farmer's decision making: A reinterpretation. Journal of Development Studies, 20(1): 503-539.

Biradar, R. 2012. Incidence of poverty among social groups in rural India: Who are the poorest and why. Social and Economic Change Monographs 24, Institute for Social and Economic Change, Bangalore.

Borooah, V. K. 2005. Caste, inequality, and poverty in India. Review of Development 
Economics, 9(3): 399-414.

Buttle, E., Tu, Q., \& List, J. A. Forthcoming. Battle of the sexes: How sex ratios affect female bargaining power. Economic Development and Cultural Change.

Clark, G., \& Landes, Z. 2013. Caste versus class: Social mobility in India, 1860-2012. Working paper, Department of Economics, University of California, Davis Retrieved on August 17, 2015, from http:/www.econ.ucdavis.edu/faculty/gclark/ research.html.

Crook, R. C., \& Sverrisson, A. S. 2002. Decentralization and poverty alleviation in developing countries: A comparative analysis or, is West Bengal unique? IDS Working Paper 130, Institute of Development Studies, University of Sussex, Brighton.

Chin, A., \& Prakash, N. 2011. The redistributive effects of political reservation for minorities: Evidence from India. Journal of Development Economics, 96(2): 265-277.

Datt, G., \& Ravallion, M. 1992. Growth and redistribution components of changes in poverty measures: A decomposition with applications to Brazil and India in the 1980s. Journal of Development Economics, 38(2): 275-295.

Datt, G., \& Ravallion, M. 1998. Why have some Indian states done better than others at reducing rural poverty? Economica, 65(257): 17-38.

Deaton, A. 1992. Understanding consumption. New York: Oxford University Press.

Deshpande, A. 2000. Does caste still define disparity? A look at inequality in Kerala, India. American Economic Review, 90(2): 322-325.

Deshpande, A. 2013. Social justice through affirmative action in India. PERI Working Paper Series No. 314, Political Economy Research Institute, University of Massachusetts, Amherst.

Dev, S. M. 2012. Small farmers in India: Challenges and opportunities. IGIDR Working Paper 2012-014, Indira Gandhi Institute of Development Research, Mumbai.

Duflo, E., Fisher, G., \& Chattopadhyay, R. 2005. Efficiency and rent seeking in local government: Evidence from a randomized policy experiments in India. Working paper, Department of Economics, MIT, Cambridge, MA.

Eswaran, M., \& Kotwal, A. 1986. Access to capital and agrarian production organization. Economic Journal, 96(382): 482-498.

Finan, F., Sadoulet, E., \& de Janvry, A. 2005. Measuring the poverty reduction potential of land in rural Mexico. Journal of Development Economics, 77: 27-51.

Gang, I. N., Sen, K., \& Yun, M. 2008. Poverty in rural India: Caste and tribe. Review of Income and Wealth, 54(1): 50-70.

Hnatkovska, V., Lahiri, A., \& Paul, S. B. 2013. Breaking the caste barrier: Intergenerational mobility in India. Journal of Human Resources, 48(2): 435-473. 
Heller, P., Harilal, K. N., \& Chaudhuri, S. 2007. Building local democracy: Evaluating the impact of decentralization in Kerala, India. World Development, 35(4): 626-648.

Hur, S.-K. 2005. Exploration into the determinants of household consumption: Liquidity constraint and family characteristics. Journal of Policy Studies, 27(1): 1-37.

Imai, K., Gaiha, R., \& Kang, W. 2011. Vulnerability and poverty dynamics in Vietnam. Applied Economics, 43(25): 3603-3618.

Ito, T. 2009. Caste discrimination and transaction costs in the labor market: Evidence from rural north India. Journal of Development Economics, 88(2): 292-300.

Jha, R., Gaiha, R., \& Sharma, A. 2009. Calorie and micronutrient deprivation and poverty nutrition traps in rural India. World Development, 37(5): 982-991.

Kakwani, N. 2000. On measuring growth and inequality components of poverty with applications to Thailand. Journal of Quantitative Economics, 16: 67-80.

Kanbur, R. 2003. The policy significance of inequality decompositions. Working paper, Department of Economics, Cornell University, Ithaca, NY.

Kang, W. Forthcoming. An investigation of the determinants of household vulnerability and poverty in Korea. Journal of the Korean Economy.

Kang, W., \& Imai, K. 2012. Pro-poor growth, poverty and inequality in rural Vietnam. Journal of Asian Economics, 23(5): 527-539.

Kijima, Y. 2006. Caste and tribe inequality: Evidence from India, 1983-1999. Economic Development and Cultural Change, 54(2): 369-404.

Kim, J. 2015. 2013 Strengthening the competitiveness of smallholder farms by building cooperatives or associations. In J. Kim (ed.), Knowledge-sharing program with Brazil: Promoting agricultural innovation for nurturing smallholder farms in Brazil (pp. 23-69). Sejong: Korea Development Institute, 2013.

Klugman, J. 1994. Decentralization: A survey of literature from a human development perspective. Human Development Office Occasional Papers 13, UNDP, New York.

Kumar, V. 2014. Inequality in India: Caste and Hindu social order. Transcience, 5(1): 36-52.

Lopez, R. \& Valdes, A. 2000. Fighting rural poverty in Latin America: New evidence of the effects of education, demographics, and access to land. Economic Development and Cultural Change, 49(1): 197-211.

Mehta, A. K., \& Shah, A. 2003. Chronic poverty in India: Incidence, causes and policies. World Development, 21(3): 491-511.

Munshi, K., \& Rosenzweig, M. 2006. Traditional institutions meet the modern world: Caste, gender, and schooling choice in a globalizing economy. American Economic Review, 96(4): 1225-1252. 
Oates, W. 1972. Fiscal federalism. New York: Harcourt Brace Jovanovich.

Oaxaca, R. L. 1973. Male-female wage differentials in urban labor markets. International Economic Review, 14(3): 693-709.

Pande, R. 2003. Can mandated political representation increase policy influence for disadvantaged minorities? Theory and evidence from India. American Economic Review, 93(4): 1132-1151.

Powers, D., Yoshioka, H., \& Yun, M.-S. 2011. Multivariate decomposition for nonlinear response models. Stata Journal, 11(4): 556-576.

Putnam, R. 1993. Making democracy work: Civic traditions in modern Italy. Princeton, NJ: Princeton University Press.

Ray, J., \& Majumder, R. 2010. Educational and occupational mobility across generations in India: Social and regional dimensions. MPRA Paper No. 28539, Munich Personal RePEc Archive, Munich. Retrieved on July 23, 2015, from http://mpra. ub.uni-muenchen.de/28539.

Shorrocks, A. 2013. Decomposition procedures for distributional analysis: A unified framework based on Shapley value. Journal of Economic Inequality, 11(1): 99-126.

Singh, A. 2011. Farm income inequality and the role of caste: New evidence from India. Economic Bulletin, 31(4): 2847-2862.

Teobour, C. 1956. A pure theory of local expenditure. Journal of Political Economy, 64(5): 416-424.

Van de Walle, D., \& Gunewardena, D. 2001. Sources of ethnic inequality in Viet Nam. Journal of Development Economics, 65(1): 177-207.

Yun, M-S. 2004. Decomposition differences in the first moment. Economics Letters, 82(2): 273-280. 